logos_i_ethos_2020_1_(53), s. 231-251

DOI: http://dx.doi.org/10.15633/lie.3698

Karol Jasiński

https://orcid.org/0000-0002-7695-499X

Uniwersytet Warmińsko-Mazurski w Olsztynie

\title{
Prawda o człowieku jako fundament kultury politycznej. Główne idee Tadeusza Stycznia
}

Personalizm jako autonomiczny kierunek rozwinął się dopiero w wieku XX, lecz źródła myśli personalistycznej tkwią w koncepcjach filozoficznych Sokratesa, Platona, Arystotelesa, Boecjusza, Augusty-
Karol Jasiński - prezbiter archidiecezji warmińskiej; dr hab. nauk humanistycznych w zakresie filozofii; profesor uczelni; pracownik naukowo-dydaktyczny Wydziału Teologii UWM w Olsztynie; obszar zainteresowań: filozofia społeczna i filozofia religii.

na z Hippony, Tomasza z Akwinu, Immanuela Kanta, Maxa Schelera, Felixa Ravaissona, Bordena Parkera Bowne’a, Emmanuela Mouniera i Jacquesa Maritaina. Duże zasługi dla rozwoju personalizmu mają też myśliciele polscy, do których zalicza się między innymi Wincentego Granata, Czesława Bartnika, Józefa Tischnera i Karola Wojtyłę. Personaliści podkreślają unikalną godność każdej osoby, będącej według nich celem afirmacji zarówno w prywatnej, jak i publicznej sferze życia.

Do grona czołowych personalistów polskich należy również Tadeusz Styczeń (1931-2010), który, nawiązując do myśli swojego mistrza Karola Wojtyły, rozwinął i pogłębił jego wizję etyki. Styczeń związany był od początku swojej działalności naukowej ze środowiskiem lubelskiej szkoły filozofii klasycznej istniejącej na Katolickim Uniwersytecie Lubelskim. W pracy naukowej zajmował się metaetyką i etyką. Koncentracja badań na zagadnieniu godności człowieka przyczyniła się do wypracowania przez Stycznia szczególnej odmiany personalizmu, który nazywa 
się personalizmem etycznym. Zgodnie z tym stanowiskiem dostrzeżenie godności osoby jest źródłem powinności moralnej. Miarą zaś godności jest zdolność do ujęcia i uznania konstytuującej ją transcendentnej praw$d^{1}{ }^{1}$. Do odkrycia prawdy jest zdolna każda osoba, ponieważ dokonuje się ono w jej indywidualnym sumieniu. Odkrywanie owej prawdy winno więc być w przekonaniu Stycznia przedmiotem szczególnej troski każdego człowieka. Tym bardziej, że stanowi ona aksjologiczny fundament życia osobowego i politycznej kultury społeczeństwa.

Celem niniejszego artykułu jest prezentacja i analiza podstawowych idei dotyczących zarysowanej wyżej problematyki, dokonana na podstawie głównych pism Stycznia. Składa się on z trzech zasadniczych części. W pierwszej zostanie przedstawiona koncepcja sumienia lubelskiego personalisty. W drugiej - będzie podjęta kwestia odkrywanej w sumieniu prawdy. W trzeciej części natomiast skoncentrujemy się na zagadnieniu kultury politycznej, której występowanie jest uzależnione zdaniem Stycznia od istnienia określonego fundamentu aksjologicznego. Jest nim odkrywana w sumieniu prawda o osobowej godności każdego człowieka.

\section{Natura sumienia człowieka}

Przystępując do określenia natury sumienia, należy stwierdzić, że stajemy w obliczu niełatwego zadania. Już samo słowo „sumienie” jest wieloznaczne. Niekiedy zamiast o sumieniu mówi się o świadomości moralnej lub o stanach świadomości poszczególnych osób.

Naturę sumienia próbuje się wyjaśniać za pomocą różnych teorii. Idąc za sugestią filozofa moralności Tadeusza Ślipki, można wyróżnić trzy zasadnicze ich typy: intelektualistyczną (sumienie jako władza poznawcza), woluntarystyczną (sumienie jako skłonność woli) i emotywną (sumienie jako wyraz emocjonalnie przeżytych wartości) ${ }^{2}$. Powyższe

1 Por. K. Krajewski, Wprowadzenie. Personalizm etyczny, w: T. Styczeń, Rozum i wiara wobec pytania: Kim jestem?, Lublin 2001, s. 8-11, 17; J. Merecki, Spór o prawo naturalne. Analiza modelu argumentacji etycznej Josefa Fuchsa, Lublin 2011, s. 6, 12.

2 Zob. T. Ślipko, Zarys etyki ogólnej, Kraków 2002, s. 360-361, 364-365. 
teorie są konsekwencją faktu, że sumienie jako pewien fenomen antropologiczny ma wiele różnych wymiarów (np. intelektualny, wolitywny, społeczno-kulturowy i religijny) ${ }^{3}$. Powstanie określonej teorii sumienia jest konsekwencją wyakcentowania takiego bądź innego jego wymiaru.

W przekonaniu polskiego etyka Andrzeja Szostka sumienie jest terminem teoretycznym, a więc nie odnosi się do żadnego prostego przedmiotu lub jego cechy. Sumienia nie sposób bowiem uchwycić wprost. Za pomocą tego słowa opisuje się sytuację, w której człowiek i jego postępowanie podlega jego własnej ocenie za pomocą rozumu. W akcie poznania człowiek dystansuje się wobec siebie i jednocześnie otwiera się na poznanie siebie ${ }^{4}$. Pojęcie „sumienia” byłoby więc konstruktem teoretycznym, za pomocą którego próbowano by wyjaśnić pewien rodzaj poznania człowieka.

Wiesław Szuta akcentuje bardziej ontyczny aspekt sumienia. Jest ono jego zdaniem elementem struktury bytu ludzkiego. Stanowi „wyposażenie” rozumu, dzięki któremu człowiek ma zdolność odróżniania dobra i zła oraz oceniania pod tym kątem własnego działania ${ }^{5}$. Można zatem powiedzieć, że sumienie jest funkcją tej władzy człowieka, jaką jest rozum. Ma ono uchwycić związek istniejący między konkretnym czynem a wartościami.

Na sumienie jako bezpośrednią i obowiązującą normę czynu ludzkiego zwracają uwagę tomiści. Dzięki sumieniu człowiek stosuje prawo naturalne do konkretnych sytuacji. Sumienie jest więc aktem rozumu, który stosuje ogólne prawo do konkretnego przypadku ${ }^{6}$.

Na podstawie przytoczonych stanowisk można dojść do przekonania, że sumienie jest funkcją rozumu człowieka. Takie ujęcie zbliża nas do intelektualistycznych teorii sumienia. Wydaje się też, że sumienie nie jest w pełni autonomiczne, ponieważ kieruje się ono w swojej ocenie określonymi wartościami, normami lub zasadami prawa naturalnego.

3 Por. W. Szuta, Potrójnie o sumieniu, Kraków 2013, s. 128-138.

4 Zob. A. Szostek, Wokół godności, prawdy i miłości, Lublin 1998, s. 180-185.

5 Zob. W. Szuta, Potrójnie o sumieniu, dz. cyt., s. 15-19, 22.

6 Por. I. M. Bocheński, ABC tomizmu, Londyn 1950, s. 61-62. 
Z intelektualistyczną teorią sumienia sympatyzuje również Styczeń. Sumienie jest według niego przede wszystkim sądem, którego podmiotem jest człowiek. Sąd ten jest prawodawczy, normatywny i powinnościowy. Człowiek jest wprawdzie autorem sądu, ale nie jest autorem prawdy sądu. Prawda jest bowiem przez niego odkrywana. W sumieniu dominuje więc moment poznawczy. Samo zaś sumienie ukazuje dwupoziomową strukturę wewnętrzną podmiotu jako bytu wsobnego i transcendentnego ${ }^{7}$.

Styczeń akcentuje przede wszystkim powinnościowy i intencjonalny charakter sumienia. Koniecznym warunkiem powinności moralnej jest nakaz sumienia. Powinność moralna jest dana i zadana podmiotowi. Jej racją jest zewnętrzny świat osób i wartości, domagający się afirmacji w imię prawdy o nim. W aktach sumienia dochodzi więc do uznania prawdy określonego stanu rzeczy. Tym samym ujawnia się intencjonalny charakter sumienia, czyli jego ukierunkowanie na odkrywaną prawdę ${ }^{8}$. Związanie się ową prawdą jest fundamentem moralności. Gdy człowiek kieruje się nią, wówczas żyje w sposób moralnie godziwy ${ }^{9}$. Widać więc, że sumienie u Stycznia nie jest autonomiczne i absolutne, lecz racje swego funkcjonowania czerpie z zewnętrz.

Lubelski personalista zdaje się wręcz utożsamiaćsumieniez powinnością. Jest ono rzeczywistością, która jawi się we wnętrzu podmiotu w formie apelu. Pochodzi on od instancji transcendentnej względem podmiotu. Domaga się zajęcia określonej postawy i spełnienia określonego czynu. Jest auto-imperatywem kategorycznym, angażującym wolność człowieka ${ }^{10}$.

7 Zob. T. Styczeń, Antropologiczne podstawy etyki czy etyczne podstawy antropologii?, w: Objawiać osobę, red. T. Styczeń, Lublin 2013, s. 166-175.

8 Zob. T. Styczeń, Autorytet religijny a wiara osobista i autonomia sumienia, w: Objawiać osobę, dz. cyt., s. 320-321; T. Styczeń, Etyka niezależna?, Lublin 1980, s. 46-48, 50-51; T. Styczeń, Prawda o człowieku miara jego afirmacji. O gwarancjach zabezpieczajacych humanizm przed wyrodzeniem się w antyhumanizm, w: Objawiać osobę, dz. cyt., s. 252-253.

9 Zob. T. Styczeń, Aksjologiczne podstawy kultury politycznej, w: Człowiek darem. Życie - rodzina - państwo - prawo, red. T. Styczeń, Lublin 2014, s. 311; T. Styczeń, Moralność - wyróżnik człowieka, w: Objawiać osobę, dz. cyt., s. 227-236.

10 Zob. T. Styczeń, Sumienie: źródło wolności czy zniewolenia?, w: Objawiać osobę, dz. cyt., s. $184-186$. 
Styczeń wyróżnia kilka poziomów sumienia. Najpierw mamy do czynienia z prasumieniem (synderezą), które domaga się afirmacji dla wszystkiego, co wartościowe. Następnie mamy sumienie w sensie szerszym (podmiotową świadomość moralnej powinności) i ścisłym (sąd podmiotu wyrażający ową świadomość). W związku z tym filozof podkreśli, że sumienie jest subiektywną i subiektywnie ostateczną normą moralności ${ }^{11}$.

Zwraca jednocześnie uwagę na to, że sumienie może ulegać deformacji na trzy zasadnicze sposoby. Pierwszy polega na błędnym ujęciu natury sumienia, któremu przypisuje się kreatywność. Drugą formą deformacji jest totalitaryzm, w imię którego podporządkowuje się sumienie jakiejś wartości nadrzędnej, np. „wspaniałemu społeczeństwu”. Trzecim zagrożeniem sumienia jest konsumpcjonizm, gdy kryterium oceny jest wygoda człowieka ${ }^{12}$.

Styczeń podejmuje polemikę zwłaszcza z kreatywną koncepcją sumienia. Jej wyrazem jest chociażby liberalizm indywidualistyczny $i$ kolektywistyczny, którego zwolennicy chcą uzależnić prawdę od wolnej twórczości lub praktyki społecznej ${ }^{13}$. Myśliciel podkreśla, że człowiek jest wówczas obwołany twórcą i projektantem nie tylko prawdy, lecz także własnej natury. Dochodzi niejako do deifikacji człowieka, któremu zostaje przyznany tytuł moralnego prawodawcy ${ }^{14}$. Ponadto koncepcja sumienia kreatywnego jest w opozycji do personalizmu. Brakuje w niej bowiem zdaniem Stycznia podstaw do sprzeniewierzenia się samemu sobie i drugiemu człowiekowi, ponieważ wszystko bazuje na wolnej umowie człowieka z samym sobą ${ }^{15}$.

11 Zob. T. Styczeń, J. Merecki, ABC etyki, w: Objawiać osobę, dz. cyt., s. 404-407.

12 Zob. T. Styczeń, Sumienie a Europa, czyli gdyby Ojciec święty zaprosił Arystotelesa na Synod Biskupów Europy 1991, w: Solidarność wyzwala, red. T. Styczeń, Lublin 1993, s. 209-210.

13 Zob. T. Styczeń, A. Szostek, Liberalizm po marksistowsku. Antropologiczne implikacje marksistowskiej soteriologii, w: Człowiek darem. Życie - rodzina - państwo - prawo, dz. cyt., s. 329-347.

14 Zob. T. Styczeń, Filozoficzna koncepcja prawa naturalnego, w: Objawiać osobę, dz. cyt., s. 219220; T. Styczeń, Sumienie a Europa..., dz. cyt., s. 208-209.

15 Zob. T. Styczeń, Być sobą to przekraczać siebie. O antropologii Karola Wojtyły, w: Rozum i wiara wobec pytania: Kim jestem?, dz. cyt., s. 65-68; T. Styczeń, Problem człowieka problemem miłości, w: Objawiać osobę, dz. cyt., s. 144. 
Filozof widzi w związku z tym potrzebę odróżnienia aktu poznania (cognosco) od aktu myślenia (cogito). W akcie poznania człowiek poddaje się prawdzie świata. W akcie myślenia natomiast ustanawia i kształtuje prawdę. Bycie osobą domaga się jednak w przekonaniu Stycznia poznawczego kontaktu z prawdą realnego świata, a nie jej dowolnej kreacji ${ }^{16}$. Poznawczy kontakt $\mathrm{z}$ niezależną od podmiotu prawdą świata osób i wartości zachodzi właśnie w sumieniu człowieka, które odczytuje sensy, lecz ich arbitralnie nie tworzy.

Obiekcje Stycznia podzielają też jego uczniowie i kontynuatorzy myśli, do których zalicza się Andrzeja Szostka i Jarosława Mereckiego. Zwracają oni uwagę na dwie zasadnicze kwestie związane $\mathrm{z}$ kreatywną koncepcją sumienia. Po pierwsze, rezygnuje się w niej z tradycyjnej teorii sumienia, według której orzeka ono o zgodności czynu z obiektywnym prawem moralnym. Po drugie, podkreśla się wymiar podmiotowy poprzez dowartościowanie niepowtarzalności podmiotu, jego samorozumienia oraz autentyczności ${ }^{17}$. W koncepcji sumienia kreatywnego, w przeciwieństwie do jego tradycyjnej teorii, element podmiotowy i subiektywny zyskuje $\mathrm{w}$ ich przekonaniu przewagę nad przedmiotowym i obiektywnym.

Szostek pragnie więc dowartościować przedmiotowy charakter sumienia, które jest świadkiem prawdy. Stawia ono bowiem człowieka i jego czyny w obliczu prawa Bożego, wypisanego w ludzkim sercu. Jest ono wyrazem zamysłu Bożego dotyczącego człowieka, a jednocześnie pokazaniem jego aktualnego stanu ${ }^{18}$. W przekonaniu Mereckiego można zaś mówić w pewnym sensie o sumieniu kreatywnym. Jego twórczość polega jednak wyłącznie na tym, że odnosi ono określoną normę moralną do konkretnej sytuacji ${ }^{19}$. Widać więc, że zarówno sam Styczeń, jak i kontynuatorzy jego myśli podkreślają związek sumienia z obiektywną

16 Zob. T. Styczeń, Na początku była prawda. U genezy pojęcia osoby, w: Rozum i wiara wobec pytania: Kim jestem?, dz. cyt., s. 102-103.

17 Zob. J. Merecki, Spór o prawo naturalne..., dz. cyt., s. 89-104; A. Szostek, Natura, rozum, wolność, Rzym 1990, s. 120-121.151-156.

18 Zob. A. Szostek, Wokót godności, prawdy i miłości, dz. cyt., s. 140, 143-148, 158-159.

19 Zob. J. Merecki, Spór o prawo naturalne..., dz. cyt., s. 151. 
prawdą stanu rzeczy. Nie jest ona przez człowieka kreowana, lecz jedynie odczytana $\mathrm{w}$ formie zasad prawa naturalnego i norm moralnych formułowanych i wyrażanych w sądach sumienia.

\section{Prawda odkrywana przez sumienie}

Sumienie poznaje zatem prawdę i wyraża ją w aktach sądzenia, a wydawane przez człowieka sądy mają charakter powinnościowy. Należałoby zatem postawić dwa ważne pytania: co jest przedmiotem powinności i jaką prawdę odkrywa sumienie?

Styczeń daje w tej kwestii jasną odpowiedź. W jego przekonaniu człowiek odkrywa w sumieniu przede wszystkim powinność afirmowania prawdy o dobru. Zasadniczym dobrem jest natomiast godność człowieka, dzięki której domaga się on afirmacji ${ }^{20}$. Godność osoby jest więc przedmiotem powinności moralnej ${ }^{21}$. Godność ma zdaniem filozofa związek z następującymi cechami osoby: niepowtarzalnością ${ }^{22}$, niezastępowalnością ${ }^{23}$, niekomunikowalnością ${ }^{24}$, jedynością i nieporównywalnością ${ }^{25}$.

Na marginesie warto przypomnieć, że termin „godność osoby” został zaproponowany przez Immanuela Kanta w celu podkreślenia nadrzędnej roli osoby w moralności. Za jego pomocą chciał on wyrazić intuicję, że wartości osoby nie można postawić na jednym poziomie $\mathrm{z}$ innymi wartościami ${ }^{26}$. Godność ma związek z osobą jako bytem duchowo-cielesnym, dla którego znamienna jest zdolność rozumnego i wolnego samostanowienia oraz bezinteresownej miłości ${ }^{27}$. W imię

20 Zob. T. Styczeń, Antropologiczne podstawy etyki czy etyczne podstawy antropologii?, dz. cyt., s. $171-174$.

21 Zob. T. Styczeń, Etyka niezależna?, dz. cyt., s. 72.

22 Zob. T. Styczeń, Człowiek jako podmiot daru z samego siebie. Antropologia adhortacji „Familiaris consortio”, w: Człowiek darem. Życie - rodzina - państwo - prawo, dz. cyt., s. 73.

23 Zob. T. Styczeń, Ciało jako „znak obrazu Stwórcy”, w: Człowiek darem. Życie - rodzina - państwo - prawo, dz. cyt., s. 142.

24 Zob. T. Styczeń, Etyka niezależna?, dz. cyt., s. 30.

25 Zob. T. Styczeń, Objawiać osobę, w: Objawiać osobę, dz. cyt., s. 22.

26 Por. J. Merecki, Spór o prawo naturalne..., dz. cyt., s. 162.

27 Por. A. Szostek, Wokót godności, prawdy i miłości, dz. cyt., s. 60. 
owej godności człowieka należy traktować jako cel sam w sobie, a nie tylko jako środek do innych celów ${ }^{28}$. Godność człowieka można uzasadnić w sposób nie tylko rozumowy (otwartość na wartości), lecz także religijny (bycie obrazem Boga ${ }^{29}$. Przekonanie o religijnym uzasadnieniu godności osoby ludzkiej bliskie jest również Styczniowi. Podkreśla on, że istnienie i godność człowieka mają bezpośrednie źródło w akcie stwórczym osobowego Absolutu ${ }^{30}$. Człowiek z racji swego pochodzenia i natury winien być zatem nie tylko źródłem, ale też normą wszelkiego działania moralnego.

Zasadniczą prawdą odkrywaną w sumieniu jest zatem zdaniem Stycznia prawda o godności osoby, dzięki której domaga się ona afirmacji w sposób bezwarunkowy, bezinteresowny i bezwzględny. Na afirmowaniu osoby z racji jej godności polega też istota powinności moralnej, która przybiera formę relacji międzyosobowej ${ }^{31}$. Afirmacja osoby jest u tego myśliciela innym określeniem miłości jako drogi do samospełnienia $^{32}$. Postawie afirmacji sprzeciwia się natomiast instrumentalne odniesienie do człowieka ${ }^{33}$.

W tym kontekście na ważną kwestię zwraca uwagę Szostek. Zauważa on, że odróżnia się niekiedy godność osobową od godności osobowościowej. Pierwsza ma związek z ontyczną strukturą bytu, druga natomiast $\mathrm{z}$ działaniem polegającym na afirmacji osoby ${ }^{34}$. Można więc powiedzieć, że pierwsza ma charakter ontyczny, a druga - moralny. Wydaje się,

28 Por. A. Szostek, Natura, rozum, wolność, dz. cyt., s. 47.

29 Por. M. Zięba, Papieże i kapitalizm: od „Rerum novarum” po „Centesimus annus”, Kraków 1998, s. 162-167.

30 Zob. T. Styczeń, Ciało jako „znak obrazu Stwórcy”, dz. cyt., s. 138.

31 Zob. T. Styczeń, Człowiek w polu odpowiedzialności za siebie i drugich, w: Solidarność wyzwala, dz. cyt., s. 40-44; T. Styczeń, Etyka niezależna?, dz. cyt., s. 52-53, 70, 80; T. Styczeń, Filozoficzna koncepcja prawa naturalnego, dz. cyt., s. 205-209.

${ }_{32}$ Zob. T. Styczeń, Człowiek jako podmiot daru z samego siebie..., dz. cyt., s. 45; T. Styczeń, Osoba - podmiot we wspólnocie, w: Objawiać osobę, dz. cyt., s. 49-50.

33 Zob. T. Styczeń, Ciało jako „znak obrazu Stwórcy”, dz. cyt., s. 136-137; T. Styczeń, Człowiek jako podmiot daru z samego siebie..., dz. cyt., s. 92; T. Styczeń, Etyka niezależna?, dz. cyt., s. 31, 5254; T. Styczeń, Problem człowieka problemem miłości, dz. cyt., s. 121-122, 131.

34 Zob. A. Szostek, Wokół godności, prawdy i miłości, dz. cyt., s. 45-46. 
że Styczeń koncentruje się bardziej na wynikającej z ontycznego statusu godności osobowej.

Podkreśla on zatem, że godność osobowa wyrasta z samej struktury bytowej człowieka i całą tę strukturę przenika ${ }^{35}$. Wyrazem owej struktury jest określony sposób bytowania i działania. Szczególnym jego przejawem jest zdolność człowieka do wydawania powinnościowych sądów sumienia, dzięki którym przekracza on siebie w stronę rozpoznanej prawdy. Człowiek wiąże się nią w swoim wnętrzu i zaczyna się nią kierować w życiu. Staje się tym samym autonomiczny ${ }^{36}$. Dzięki owej transcendencji w kierunku prawdy, ujawnianej w sumieniu, człowiek staje się osobą. Można więc powiedzieć, że transcendencja jest niejako drugim imieniem osoby i stanowi szczególny rys jej struktury ${ }^{37}$. Warte wyartykułowania są w tym miejscu dwie ważne kwestie. Po pierwsze, Styczniowi bliskie jest przekonanie o bytowym fundamencie działania (agere sequitur esse). Każde działanie zakłada istnienie określonych struktur, które są warunkiem jego zaistnienia. Po drugie, zasadniczą strukturą osoby jest jej transcendencja w kierunku prawdy. Filozof zdaje się tym samym ujmować osobę nie tyle w perspektywie ontycznej, ile raczej moralnej.

W związku z tym powtórzy on za Seneką - „homo homini res sacra”. Dzięki swemu osobowemu bytowi człowiek jest zdaniem Stycznia wartością nadrzędną wobec innych wartości ${ }^{38}$. Myśliciel będzie ponadto mocno akcentował, że człowiek jest zawsze osobą i nie można go sprowadzać do poziomu rzeczy. W konsekwencji nie wolno się nim posłużyć jak przedmiotem, lecz winno się zawsze eksponować osobowy charakter

35 Por. T. Styczeń, J. Merecki, ABC etyki, dz. cyt., s. 397.

36 Zob. T. Styczeń, Człowiek w polu odpowiedzialności za siebie i drugich, dz. cyt., s. 35-40; T. Styczeń, Człowiek jako podmiot daru z samego siebie..., dz. cyt., s. 48-56; T. Styczeń, Na początku była prawda..., dz. cyt., s. 90-91; T. Styczeń, Osoba - podmiot we wspólnocie, dz. cyt., s. 48, 51-56; T. Styczeń, Problem człowieka problemem miłości, dz. cyt., s. 135-136; T. Styczeń, Sumienie: źródło wolności czy zniewolenia?, dz. cyt., s. 187-194.

37 Zob. T. Styczeń, Być soba to przekraczać siebie..., dz. cyt., s. 48-49; T. Styczeń, Na początku była prawda..., dz. cyt., s. 100, 105; T. Styczeń, Osoba - podmiot we wspólnocie, dz. cyt., s. 42.

38 Zob. T. Styczeń, Aksjologiczne podstawy kultury politycznej, dz. cyt., s. 310, 316. 
jego egzystencji ${ }^{39}$. Można zatem powiedzieć, że każdy człowiek jest wartością wsobną, ale jest też wezwany do potwierdzenia w działaniu wartości innej osoby poprzez wyakcentowanie inności i wyjątkowości jej egzystencji.

Prawda o godności osobowej jest związana u Stycznia z prawdą o istnieniu jako darze. Na darmowość ludzkiego istnienia naprowadza nas w jego przekonaniu fakt bytowej przygodności człowieka. Człowiek istnieje więc $\mathrm{z}$ daru. Lubelski personalista zauważa trafnie, że nie ma jednak daru bez dawcy. Jest nim Bóg-Stwórca. Powołując człowieka do bytu, obdarza go jednocześnie Nim samym, ponieważ działa nieprzerwanie w człowieku ${ }^{40}$. Człowiek jest zatem darem Absolutu. Bóg wzywa go do istnienia. Co więcej, człowiek żyje, uczestnicząc w $\mathrm{Nim}^{41}$. Jest więc wezwany nie tylko do przyjęcia siebie jako daru danego przez Boga, lecz także do przyjęcia samego Boga jako Dawcy ${ }^{42}$. Bóg jest bowiem ostatecznym wyjaśnieniem i racją istnienia osób i rzeczy. Ponadto w każdym ludzkim „ty” ujawnia się realna współobecność „Ty” absolutnego. Dzięki niej osoba staje się w przekonaniu Stycznia miejscem teofanii. Jej istnienie tłumaczy się bezsprzecznie jedynie ingerencją stwórczą osobowego Absolutu, będącego jednocześnie źródłem istnienia powinności moralnej. Byt transcendentny objawia się w każdym bycie osobowym poprzez stwórcze konstytuowanie jego bytowości, ale jednocześnie ukrywa za powinnością afirmowania każdego człowieka ${ }^{43}$.

Stwierdzenie przygodności człowieka jest również w przekonaniu filozofa stwierdzeniem zależności jego natury od Absolutu. Sumienie zatem czerpie swoją treść $\mathrm{z}$ natury ludzkiej, która normuje postępowanie człowieka, ponieważ sama jest normowana przez zamysł Boga.

39 Zob. T. Styczeń, Dlaczego obrona życia nienarodzonego?, w: Człowiek darem. Życie - rodzina-państwo - prawo, dz. cyt., s. 298.

40 Zob. T. Styczeń, Człowiek jako podmiot daru z samego siebie..., dz. cyt., s. 63-66, 76-77; T. Styczeń, Żyć to dziękować, w: Człowiek darem. Życie - rodzina - państwo - prawo, dz. cyt., s. 25-27.

41 Zob. T. Styczeń, Dlaczego obrona życia nienarodzonego?, dz. cyt., s. 300.

42 Zob. T. Styczeń, Żyć to dziękować, dz. cyt., s. 28-29.

43 Zob. T. Styczeń, Etyka niezależna?, dz. cyt., s. 78-82, 85; T. Styczeń, J. Merecki, ABC etyki, dz. cyt., s. 408. 
W świetle faktu przygodności próba przypisania człowiekowi mocy konstytuowania swej natury jest zdradą prawdy o człowieku. Jest uleganiem odwiecznej pokusie, aby być jak Bóg. Człowiek jest tymczasem miejscem uobecniania się Absolutu ${ }^{44}$. Analiza osoby ludzkiej prowadzi zatem do odkrycia zapisanego $\mathrm{w}$ niej prawa naturalnego, będącego odbiciem zamysłów Boga. Zamysły te nazywa się niekiedy prawem wiecznym.

W tej sytuacji funkcją rozumu (sumienia) jest według Stycznia wyczytywanie sensów tkwiących immanentnie w naturze jako zamiarów Boga względem człowieka. Odkrywa on immanentną prawdę natury jako prawdę transcendentną, czyli odwieczny zamysł Boga ${ }^{45}$.

Człowiek winien więc przyjąć zdaniem myśliciela prawdę o nim wpisaną w jego byt przez osobowego Dawcę. Jest to prawda daru, która determinuje normę personalistyczną jako zasadę odnoszenia się do osoby ludzkiej i osoby Dawcy. Stwórca stworzył człowieka i wezwał do jego afirmacji. Relacja z człowiekiem jest więc sprawdzianem i wykładnikiem więzi ze Stwórcą. Jest też miarą afirmacji nie tylko człowieka, lecz także $\mathrm{Boga}^{46}$.

Co więcej, prawdę tę każdy człowiek musi poznać i wybrać samodzielnie. Druga osoba może jedynie służyć pomocą w tym względzie. Człowiek staje zatem w przekonaniu Stycznia w „potrzasku” $\mathrm{i}$ "matni” prawdy. Staje w obliczu wyboru, którego nie może uniknąć. Nie może bowiem potwierdzić samego siebie inaczej, jak tylko potwierdzając aktem wyboru poznaną wcześniej prawdę. Nie może się jej sprzeniewierzyć, nie sprzeniewierzając się samemu sobie. Jeśli to jednak uczyni, doświadczy wewnętrznego rozdarcia i zakłamania nswego bytu ${ }^{47}$.

44 Zob. T. Styczeń, Filozoficzna koncepcja prawa naturalnego, dz. cyt., s. 206-214; T. Styczeń, Prawda o człowieku miara jego afirmacji..., dz. cyt., s. 255-256.

45 Zob. T. Styczeń, Filozoficzna koncepcja prawa naturalnego, dz. cyt., s. 219-222.

46 Zob. T. Styczeń, Osoba - podmiot we wspólnocie, dz. cyt., s. 62-66.

47 Zob. T. Styczeń, Być soba to przekraczać siebie..., dz. cyt., s. 34, 43, 46; T. Styczeń, Na poczatku była prawda..., dz. cyt., s. 89, 93; T. Styczeń, Sumienie: źródło wolności czy zniewolenia?, dz. cyt., s. $180-181$. 
Można powiedzieć, że sumienie jest dla lubelskiego personalisty przestrzenią poznania prawdy i doświadczenia wolności ${ }^{48}$. Co więcej, prawda poznana $\mathrm{w}$ sumieniu jest miarą wolności człowieka. Uznaje on w swoim wnętrzu prawdę aktem wolności, wiąże się nią i zaczyna stanowić o sobie poprzez kierowanie się prawdą i odpowiadanie na jej wezwania ${ }^{49}$. Człowiek jest zatem skazany na wolność, którą ujawnia sumienie. Co więcej, jest wolny poprzez sumienie ${ }^{50}$. Poddając się prawdzie odkrytej w sumieniu, przyczynia się jednocześnie do uszlachetnienia swej wolności ${ }^{51}$.

W związku z tym, idąc za myślą Arystotelesa, Styczeń podkreśla rolę „prawego sumienia”. Uważa, że sądy sumienia winny być poddawane ciągłej kontroli. Sumienie bowiem dojrzewa do prawości i w prawości, widząc coraz lepiej prawdę o człowieku i bardziej do niej przylegając $c^{52}$. Człowiek winien więc cały czas badać kondycję swojego sumienia. Wyłącznie bowiem prawe sumienie może być w przekonaniu filozofa rzetelnym narzędziem poznania i normą działania.

\section{Odkryta prawda a kultura polityczna}

Odkrycie prawdy o godności i darmowości istnienia osoby ludzkiej jest ważne nie tylko w kontekście moralnej egzystencji jednostki, ale również życia społeczno-politycznego. Życie to winno bazować przede wszystkim na określonej kulturze obywatelskiej i politycznej. Warto może postawić w tym miejscu pytanie - czym jest owa kultura? Tym bardziej, że zwłaszcza drugie z tych pojęć nie jest obce również Styczniowi.

Należy podkreślić, że kultura obywatelska jest pojęciem szerszym niż kultura polityczna. Kultura polityczna może być bowiem traktowana jako część składowa kultury obywatelskiej. Do działalności politycznej zalicza się m.in. kandydowanie i głosowanie w wyborach, udział

\footnotetext{
48 Zob. T. Styczeń, Człowiek w polu odpowiedzialności za siebie i drugich, dz. cyt., s. 33-35.

49 Zob. T. Styczeń, Człowiek jako podmiot daru z samego siebie..., dz. cyt., s. 90-92.

50 Zob. T. Styczeń, Sumienie: źródło wolności czy zniewolenia?, dz. cyt., s. 181-182.

51 Zob. T. Styczeń, Być soba to przekraczać siebie..., dz. cyt., s. 47.

52 Zob. T. Styczeń, Sumienie a Europa..., dz. cyt., s. 203-205.
} 
w demonstracjach, wyrażanie opinii politycznych. Na kulturę obywatelską składa się natomiast poziom zaufania, normy, więzi, współpraca i zaangażowanie obywatelskie ${ }^{53}$. Można zatem powiedzieć, że w kulturze obywatelskiej zasadniczą rolę odgrywają oparte na zaufaniu więzy międzyludzkie i wrażliwość na wartości duchowo-moralne, a nie procedury i instytucje, jak w przypadku kultury politycznej.

Mianem kultury politycznej, idąc za myślą niemieckiego filozofa Maxa Webera, można więc określić sposób i styl uprawiania polityki z jej instytucjami, działaniami i stosunkami społecznymi ${ }^{54}$. Polski socjolog Jerzy J. Wiatr definiuje natomiast kulturę polityczną jako ogół postaw, wartości i wzorów zachowań dotyczących wzajemnych stosunków władzy i obywateli. Kultura polityczna jest według niego związana z ustrojami politycznymi i leżącymi u ich podstaw formacjami społeczno-politycznymi ${ }^{55}$. W kulturze politycznej akcentuje się zatem zinstytucjonalizowane formy relacji między obywatelami i władzą, których celem jest uprawianie skutecznej polityki.

Oczywiście między wspomnianymi odmianami kultury istnieje zależność. Kultura polityczna może dobrze funkcjonować tylko w takim systemie politycznym, w którym istnieje rozwinięte społeczeństwo obywatelskie. Wówczas spełnia ona pewne istotne funkcje. Najczęściej wymienia się trzy zasadnicze: socjalizacyjną, integracyjną i regulacyjną. Przejawem funkcji socjalizacyjnej jest proces angażowania się członków społeczeństwa w życie polityczne. Funkcja integracyjna wyraża się w uzyskaniu zgodności w kwestii podstawowej struktury systemu i przynależności do danej wspólnoty politycznej. Funkcja regulacyjna ma natomiast związek $\mathrm{z}$ tworzeniem norm i instytucji określających funkcjonowanie systemu politycznego ${ }^{56}$.

Zagadnienie kultury politycznej nie umknęło też uwadze Stycznia. Przez kulturę polityczną rozumie on kulturę człowieka jako obywatela

53 Por. E. Wnuk-Lipiński, Socjologia życia publicznego, Warszawa 2008, s. 160-162.

54 Por. H. Sommer, Wybrane komponenty kultury politycznej i ich wplyw na percepcję państwa, „Humanities and Social Sciences” 1 (2015), s. 221.

55 Zob. J. J. Wiatr, Socjologia polityki, Warszawa 1999, s. 189, 192.

56 Por. H. Sommer, Wybrane komponenty kultury politycznej..., dz. cyt., s. 222-223. 
swego państwa, czyli czynnego podmiotu współuczestnictwa w solidarnej trosce o dobro wszystkich bez wyjątku osób zamieszkałych na obszarze danego państwa. Troska o każdego człowieka wynika z faktu, że jest on ontyczno-aksjologicznym absolutem, domagającym się bezwarunkowej afirmacji. Fundamentem kultury politycznej jest więc w przekonaniu myśliciela prawda o człowieku ${ }^{57}$. Przyglądając się powyższemu określeniu kultury politycznej przez Stycznia, można dojść do przekonania, że zwraca on większą uwagę na jej aspekty moralne, niż na konkretne instytucje i mechanizmy sprawowania władzy. Wydaje się, że sposób jej rozumienia jest więc bliższy pojęciu kultury obywatelskiej. Podstawą owej kultury jest prawda o człowieku i jego osobowej godności, która winna być odkryta i zinterioryzowana.

W imię owej prawdy zasadniczym elementem kultury politycznej u lubelskiego personalisty jest etos, którego sednem jest afirmacja osobowej podmiotowości bytu ludzkiego. Na tym etosie opiera się państwo. Miłość jako akt afirmowania drugiego człowieka w czynie jest spoiwem wiążącym ludzi w jedną wspólnotę. Jako więź osobowa stanowi podstawę fundującą i określającą wszelkie inne więzi międzyludzkie oraz nadającą im tożsamość. Miłość jest też kryterium autentycznego i trwałego współdziałania. Dzięki niej dokonuje się personalizacja więzi społecznych ${ }^{58}$.

Wyrazem afirmacji winno być czynne współuczestnictwo w trosce o dobro innych, będące istotnym elementem kultury politycznej. Współuczestnictwo jest przejawem natury człowieka będącego nie tyle odizolowaną substancją, ile bytem wezwanym do życia we wspólnocie ${ }^{59}$. Styczeń proponuje zatem integralne spojrzenie na osobę jako podmiot substancjalny i byt relacyjny, który domaga się realizacji w obu wymiarach swej egzystencji. Tym samym ujawnia się nowy wymiar transcendencji człowieka, nie tylko wychodzącego w stronę prawdy o sobie, lecz także w kierunku złożonej z osób wspólnoty.

57 Zob. T. Styczeń, Aksjologiczne podstawy kultury politycznej, dz. cyt., s. 305-306, 311.

58 Zob. T. Styczeń, Osoba - podmiot we wspólnocie, dz. cyt., s. 61-62; T. Styczeń, O etos dla prawa, w: Człowiek darem. Życie - rodzina - państwo - prawo, dz. cyt., s. 319-321, 323, 326.

59 Zob. T. Styczeń, Człowiek jako podmiot daru z samego siebie..., dz. cyt., s. 102. 
Transcendencja osoby jest warunkiem istnienia państwa, którego pierwszym celem jest zdaniem filozofa zabezpieczenie podmiotowości osoby. Stanowi ono istotny składnik kultury politycznej. Rdzeniem podmiotowości jest autonomia, samozależność i samorządność w świetle poznanej prawdy ${ }^{60}$. W imię szacunku dla podmiotowości osoby nie powinno się jej zmuszać, ani oczekiwać od niej, by sprzeniewierzyła się własnemu sumieniu. Respektowanie podmiotowości jest związane $\mathrm{z}$ respektowaniem autonomii sumienia każdego człowieka ${ }^{61}$. W związku z tym należałoby dowartościować w przekonaniu Szuty znaczenie indywidualnego sumienia jako normy działania na forum publicznym ${ }^{62}$.

Nieodłącznym elementem kultury politycznej jest też u Stycznia koncepcja państwa jako instytucji chroniącej fundamentalne dobro, jakim jest życie ludzkie. Jeśli sprzeniewierza się ono temu zadaniu, to dopuszcza się bezprawia. Dochodzi wtedy nie tylko do zakłamania państwa, lecz także do autodestrukcji podmiotu ludzkiego. Lubelski filozof ma na uwadze życie każdego bez wyjątku człowieka, również tego jeszcze nienarodzonego. Tym bardziej, że człowiek nienarodzony nie różni się niczym w swej godności od człowieka narodzonego. Obu przysługują z natury pewne prawa, wśród których prawo do życia jest fundamentalne. Życie każdego z nich domaga się więc absolutnego respektu. Kamieniem probierczym kultury politycznej i państwa jest zatem w przekonaniu Stycznia stosunek do życia człowieka nienarodzonego. W związku z tym dopomina się on o stworzenie jakiegoś wzorca społeczeństwa autentycznie demokratycznego, którego obecnie brakuje. Powinien być on ukształtowany na miarę ochrony życia najsłabszej osoby ${ }^{63}$. Pod tym pojęciem myśliciel rozumie nade wszystko człowieka nienarodzonego.

60 Zob. T. Styczeń, Człowiek $w$ polu odpowiedzialności za siebie i drugich, dz. cyt., s. 46-47; T. Styczeń, O etos dla prawa, dz. cyt., s. 324-325.

${ }_{61}$ Zob. T. Styczeń, Autorytet religijny a wiara osobista i autonomia sumienia, dz. cyt., s. 329-330.

${ }_{62}$ Zob. W. Szuta, Potrójnie o sumieniu, dz. cyt., s. 19-20.

63 Zob. T. Styczeń, Nienarodzony - miara i szansa demokracji, w: Człowiek darem. Życie - rodzina - państwo - prawo, dz. cyt., s. 377-386; T. Styczeń, Sprawa nienarodzonego na politycznym areopagu. Państwo solidarne z nienarodzonym czy totalitaryzmu ciąg dalszy?, w: Solidarność wyzwala, dz. cyt., s. 146; T. Styczeń, Wolność i prawo za czy przeciw życiu? Etyk wobec „nieskuteczności” prawdy, w: Człowiek darem. Życie-rodzina-państwo-prawo, dz. cyt., s. 394-402. 
Na kulturę polityczną składa się również troska o zabezpieczenie praw mniejszości (np. narodowych, wyznaniowych). Styczeń raz jeszcze przypomina słynną dewizę Seneki „homo homini res sacra”, która winna być zasadą stojącą u podstaw państwa i prawa ${ }^{64}$. $\mathrm{Na}$ forum publicznym należy kierować się zasadą pluralizmu i zasadą dialogu. Pierwsza jest wyrazem respektu należnemu drugiemu człowiekowi z tytułu jego wierności odkrytej w sumieniu prawdzie. Druga natomiast - wyrazem troski o prawdę transsubiektywną ${ }^{65}$. Wydaje się, że postulowany dialog jest konieczny zwłaszcza w dzisiejszych społeczeństwach wielokulturowych i wieloreligijnych, ponieważ może się przyczynić do lepszego poznania prawdy, eliminacji przynajmniej niektórych uprzedzeń i osiągnięcia porozumienia.

\section{Zakończenie}

Celem powyższych rozważań była prezentacja i analiza głównych idei Stycznia dotyczących odkrywania w sumieniu prawdy o człowieku, będącej podstawą kultury politycznej. Przedstawiono w nich najpierw koncepcję sumienia lubelskiego personalisty, następnie podjęto kwestię charakteru odkrywanej w sumieniu prawdy i w końcu skoncentrowano się na zagadnieniu kultury politycznej. Istnienie kultury politycznej jest uzależnione zdaniem Stycznia od istnienia fundamentu aksjologicznego, którym jest prawda o człowieku, zwłaszcza jego osobowej godności.

Wydaje się, że myśliciel zwraca uwagę na kilka zasadniczych spraw. Po pierwsze, akcentuje on osobową godność człowieka jako jego wewnętrzną wartość. Przysługuje ona bytowi ludzkiemu na mocy samego istnienia, a nie ze względu na jego jakość, kwalifikacje czy miejsce w strukturze społecznej. Po drugie, odpowiednim i jedynym sposobem odniesienia do człowieka $\mathrm{z}$ racji jego godności jest afirmacja, która staje się naczelną zasadą personalizmu. Moralność polega na akcie afirmacji,

64 Zob. T. Styczeń, Homo homini res sacra. W sprawie aksjologicznej zasady Konstytucji Rzeczypospolitej Polskiej, w: Solidarność wyzwala, dz. cyt., s. 139-140.

${ }_{65}$ Zob. T. Styczeń, Aksjologiczne podstawy kultury politycznej, dz. cyt., s. 314. 
czyli potwierdzenia człowieka jako człowieka. Po trzecie, Styczeń szuka dla owej godności ostatecznej racji, którą można odnaleźć w porządku naturalnym w rozumnej i wolnej naturze ludzkiej, natomiast w porządku nadnaturalnym w stwórczym akcie i zamyśle Absolutu. Natura osobowa jest więc normatywna dla ludzkiego postępowania, ale sama jest też normowana przez Absolut. Natura nie jest zdaniem lubelskiego personalisty zupełnie plastyczna, lecz jest określoną statyczno-dynamiczną strukturą determinującą następnie ludzkie działanie. Po czwarte, Styczeń jest optymistą poznawczym, ponieważ uważa, że człowiek może poznać prawdę. $\mathrm{W}$ czasach sceptycyzmu w tej materii jego postawa jest godna uwagi. Poznanie dokonuje się za pomocą sumienia, będącego funkcją rozumu ukierunkowanego na wydawanie sądów normatywno-oceniających dotyczących czynów człowieka. Filozof podkreśla z mocą, że sumienie nie jest kreatywne, lecz receptywne. Odkrywa bowiem prawdę o godności człowieka, która staje się punktem odniesienia i normą dla ludzkiego postępowania. Po piąte, prawda o człowieku jest aksjologicznym fundamentem kultury politycznej. Rzeczą godną podkreślenia jest to, że Styczeń zwraca w ogóle uwagę na potrzebę kultury w życiu politycznym. Co więcej, nie można w jego przekonaniu oddzielać polityki od moralności, co próbuje się coraz częściej czynić. Polityka zakłada określoną kulturę polityczną, której podstawą jest odpowiednia aksjologia. Po szóste, dzięki prawdzie o godności osobowej poznajemy naturę samego człowieka, zyskujemy wartość stanowiącą fundament systemu politycznego, otrzymujemy kryterium oceny zjawisk i instytucji politycznych oraz łatwiej kształtujemy wzory odpowiednich zachowań w sferze polityki. Prawda o osobowej godności człowieka jest również czynnikiem socjalizującym ludzi, ponieważ formuje ich poglądy i opinie; czynnikiem integrującym system społeczno-polityczny, ponieważ wskazuje główną jego wartość; oraz regulującym, ponieważ pomaga stworzyć nie tylko odpowiednie instytucje, lecz także normy i zasady funkcjonowania systemu politycznego. Po siódme, zasadniczym przejawem owej kultury jest uczestnictwo w trosce o dobro każdego człowieka, afirmacja podmiotowości osoby ludzkiej, dowartościowanie autonomii jej sumienia, ochrona każdej formy życia człowieka i zabezpieczenie praw mniejszości. W życiu różnych 
jednostek i społeczności może wprawdzie dochodzić do konfliktu między poszczególnymi elementami, ale swoistym antidotum w tej sytuacji byłby dialog jako jeden $\mathrm{z}$ zasadniczych sposobów rozwiązywania sporów. Kwestią otwartą pozostaje pytanie, czy Styczeń nie przecenia przypadkiem roli dialogu. Rozmowa między ludźmi może bowiem niekiedy tylko pogłębić konflikt, a nie go rozwiązać. Niemniej jednak konsensus będący wynikiem dialogu wydaje się być jedyną możliwością w życiu i funkcjonowaniu społeczeństw pluralistycznych. Jest on też istotnym wyrazem kultury politycznej.

\section{Bibliografia}

Bocheński I. M., ABC tomizmu, Londyn 1950.

Krajewski K., Wprowadzenie. Personalizm etyczny, w: T. Styczeń, Rozum i wiara wobec pytania: Kim jestem?, Lublin 2001, s. 7-17.

Merecki J., Spór o prawo naturalne. Analiza modelu argumentacji etycznej Josefa Fuchsa, Lublin 2011.

Sommer H., Wybrane komponenty kultury politycznej $i$ ich wplyw na percepcję państwa, „Humanities and Social Sciences” 1 (2015), s. 219-230.

Styczeń T., Aksjologiczne podstawy kultury politycznej, w: Człowiek darem. Życie - rodzina - państwo - prawo, red. T. Styczeń, Lublin 2014, s. 305-318.

Styczeń T., Antropologiczne podstawy etyki czy etyczne podstawy antropologii?, w: Objawiać osobę, red. T. Styczeń, Lublin 2013, s. 163-175.

Styczeń T., Autorytet religijny a wiara osobista i autonomia sumienia, w: Objawiać osobę, red. T. Styczeń, Lublin 2013, s. 304-340.

Styczeń T., Być sobą to przekraczać siebie. O antropologii Karola Wojtyły, w: Rozum i wiara wobec pytania: Kim jestem?, red. T. Styczeń, Lublin 2001, s. 33-81.

Styczeń T., Ciało jako „znak obrazu Stwórcy”, w: Człowiek darem. Życie - rodzina - państwo - prawo, red. T. Styczeń, Lublin 2014, s. 115-175.

Styczeń T., Człowiek jako podmiot daru z samego siebie. Antropologia adhortacji „Familiaris consortio", w: Człowiek darem. Życie - rodzina - państwo - prawo, red. T. Styczeń, Lublin 2014, s. 39-88.

Styczeń T., Człowiek w polu odpowiedzialności za siebie i drugich, w: Solidarność wyzwala, red. T. Styczeń, Lublin 1993, s. 29-56. 
Styczeń T., Dlaczego obrona życia nienarodzonego?, w: Człowiek darem. Życie - rodzina państwo - prawo, red. T. Styczeń, Lublin 2014, s. 297-304.

Styczeń T., Etyka niezależna?, Lublin 1980.

Styczeń T., Filozoficzna koncepcja prawa naturalnego, w: Objawiać osobę, red. T. Styczeń, Lublin 2013, s. 197-224.

Styczeń T., Homo homini res sacra. W sprawie aksjologicznej zasady Konstytucji Rzeczypospolitej Polskiej, w: Solidarność wyzwala, red. T. Styczeń, Lublin 1993, s. 137-141. Styczeń T., Moralność - wyróżnik człowieka, w: Objawiać osobę, red. T. Styczeń, Lublin 2013, s. 225-248.

Styczeń T., Na początku była prawda. U genezy pojęcia osoby, w: Rozum i wiara wobec pytania: Kim jestem?, red. T. Styczeń, Lublin 2001, s. 83-106.

Styczeń T., Nienarodzony - miara i szansa demokracji, w: Człowiek darem. Życie - rodzina - państwo - prawo, red. T. Styczeń, Lublin 2014, s. 371-388.

Styczeń T., Objawiać osobę, w: Objawiać osobę, red. T. Styczeń, Lublin 2013, s. 15-25.

Styczeń T., Osoba - podmiot we wspólnocie, w: Objawiać osobę, red. T. Styczeń, Lublin 2013, s. 39-68.

Styczeń T., O etos dla prawa, w: Człowiek darem. Życie - rodzina - państwo - prawo, red.

T. Styczeń, Lublin 2014, s. 319-328.

Styczeń T., Prawda o człowieku miara jego afirmacji. O gwarancjach zabezpieczajacych humanizm przed wyrodzeniem się w antyhumanizm, w: Objawiać osobę, red. T. Styczeń, Lublin 2013, s. 249-261.

Styczeń T., Problem człowieka problemem miłości, w: Objawiać osobę, red. T. Styczeń, Lublin 2013, s. 119-145.

Styczeń T., Sprawa nienarodzonego na politycznym areopagu. Państwo solidarne z nienarodzonym czy totalitaryzmu ciag dalszy?, w: Solidarność wyzwala, red. T. Styczeń, Lublin 1993, s. 143-150.

Styczeń T., Sumienie: źródło wolności czy zniewolenia?, w: Objawiać osobę, red. T. Styczeń, Lublin 2013, s. 177-195.

Styczeń T., Sumienie a Europa, czyli gdyby Ojciec święty zaprosił Arystotelesa na Synod Biskupów Europy 1991, w: Solidarność wyzwala, red. T. Styczeń, Lublin 1993, s. 203-219. Styczeń T., Wolność i prawo za czy przeciwżyciu? Etyk wobec „nieskuteczności” prawdy, w: Człowiek darem. Życie - rodzina - państwo - prawo, red. T. Styczeń, Lublin 2014, s. 394-414. Styczeń T., Żyć to dziękować, w: Człowiek darem. Życie - rodzina - państwo - prawo, red. T. Styczeń, Lublin 2014, s. 15-35. 
Styczeń T., Merecki J., ABC etyki, w: Objawiać osobę, red. T. Styczeń, Lublin 2013, s. $375-418$.

Styczeń T., Szostek A., Liberalizm po marksistowsku. Antropologiczne implikacje mar-

ksistowskiej soteriologii, w: Człowiek darem. Życie - rodzina - państwo - prawo, red.

T. Styczeń, Lublin 2014, s. 329-347.

Szostek A., Natura, rozum, wolność, Rzym 1990.

Szostek A., Wokół godności, prawdy i miłości, Lublin 1998.

Szuta W., Potrójnie o sumieniu, Kraków 2013.

Ślipko T., Zarys etyki ogólnej, Kraków 2002.

Wiatr J. J., Socjologia polityki, Warszawa 1999.

Wnuk-Lipiński E., Socjologia życia publicznego, Warszawa 2008.

Zięba M., Papieże i kapitalizm: od „Rerum novarum” po „Centesimus annus”, Kraków 1998.

\section{Abstrakt \\ Prawda o człowieku jako fundament kultury politycznej. Główne idee Tadeusza Stycznia}

Celem autora jest przedstawienie i krytyczna analiza głównych idei polskiego personalisty Tadeusza Stycznia na temat prawdy, która jest aksjologiczną podstawą kultury politycznej. Jest nią odkryta w sumieniu prawda o osobowej godności każdego człowieka. Artykuł składa się z trzech głównych części. W pierwszej autor przedstawił koncepcję sumienia Stycznia (sumienie jako sąd prawodawczy, normatywny i powinnościowy). W części drugiej poruszono kwestię prawdy odkrytej w sumieniu (prawdy o ludzkiej godności i wyjątkowości ludzkiej egzystencji). W trzeciej części skoncentrowano się na zagadnieniu kultury politycznej w myśli Stycznia i jej istotnych elementów (etos polegający na afirmacji osoby, czynne współuczestnictwo w trosce o dobro każdego człowieka, respekt dla podmiotowości ludzkiej wyrażającej się w autonomii sumienia, służba państwa na rzecz ochrony życia wszystkich obywateli i zabezpieczenie praw mniejszości).

\section{Słowa kluczowe}

personalizm, sumienie, prawda, godność ludzka, kultura polityczna 


\section{Abstract \\ The truth about man as the foundation of political culture. The main ideas of Tadeusz Styczeń}

The author's purpose is to present and critical analyze of the main ideas of the Polish personalist Tadeusz Styczeń concerning the issues of truth, which is the axiological foundation of political culture. It is the truth about the personal dignity of every human being discovered in the conscience. The article consists of three main parts. In the first one, the author presented Styczen's concept of conscience (conscience as a legislative, normative and obligatory judgment). In the second, the issue of the truth discovered in the conscience was raised (truth about human dignity and the gratuitousness of human existence). The third part focuses on the issue of political culture and its essential elements in the thought of Styczen (ethos consisting in the affirmation of a person, active participation in the concern for the good of every human being, respect for human subjectivity expressed in the autonomy of conscience, service of the state to protect the lives of all citizens and safeguard the rights of minorities).

\section{Keywords}

personalism, conscience, truth, human dignity, political culture 